\title{
Light induced conversion of nitrogen dioxide into nitrous acid on submicron humic acid aerosol
}

\author{
K. Stemmler ${ }^{1}$, M. Ndour ${ }^{2}$, Y. Elshorbany ${ }^{3,4}$, J. Kleffmann ${ }^{3}$, B. D'Anna ${ }^{2}$, C. George ${ }^{2}$, B. Bohn ${ }^{5}$, and M. Ammann ${ }^{1}$ \\ ${ }^{1}$ Laboratory of Radio- and Environmental Chemistry, Paul Scherrer Institut, 5232 Villigen, Switzerland \\ ${ }^{2}$ Université de Lyon, Université Lyon 1, CNRS, UMR5256, IRCELYON, Institut de recherches sur la catalyse et \\ l'environnement de Lyon, Villeurbanne, 69626, France \\ ${ }^{3}$ Physikalische Chemie/FB C, Bergische Universität Wuppertal, 42097 Wuppertal, Germany \\ ${ }^{4}$ National Research Centre, Dokki, Giza, Egypt \\ ${ }^{5}$ Institut für Chemie und Dynamik der Geosphäre 2: Troposphäre, Forschungszentrum Jülich, 52425 Jülich, Germany
}

Received: 6 February 2007 - Published in Atmos. Chem. Phys. Discuss.: 27 March 2007

Revised: 19 July 2007 - Accepted: 20 July 2007 - Published: 20 August 2007

\begin{abstract}
The interactions of aerosols consisting of humic acids with gaseous nitrogen dioxide $\left(\mathrm{NO}_{2}\right)$ were investigated under different light conditions in aerosol flow tube experiments at ambient pressure and temperature. The results show that $\mathrm{NO}_{2}$ is converted on the humic acid aerosol into nitrous acid (HONO), which is released from the aerosol and can be detected in the gas phase at the reactor exit. The formation of HONO on the humic acid aerosol is strongly activated by light: In the dark, the HONO-formation was below the detection limit, but it was increasing with the intensity of the irradiation with visible light. Under simulated atmospheric conditions with respect to the actinic flux, relative humidity and $\mathrm{NO}_{2}$-concentration, reactive uptake coefficients $\gamma_{\mathrm{rxn}}$ for the $\mathrm{NO}_{2} \rightarrow \mathrm{HONO}$ conversion on the aerosol between $\gamma_{\mathrm{rxn}}$ $<10^{-7}$ (in the dark) and $\gamma_{\mathrm{rxn}}=6 \times 10^{-6}$ were observed. The observed uptake coefficients decreased with increasing $\mathrm{NO}_{2}$ concentration in the range from 2.7 to $280 \mathrm{ppb}$ and were dependent on the relative humidity $(\mathrm{RH})$ with slightly reduced values at low humidity $(<20 \% \mathrm{RH})$ and high humidity $(>60 \% \mathrm{RH})$. The measured uptake coefficients for the $\mathrm{NO}_{2} \rightarrow$ HONO conversion are too low to explain the HONOformation rates observed near the ground in rural and urban environments by the conversion of $\mathrm{NO}_{2} \rightarrow \mathrm{HONO}$ on organic aerosol surfaces, even if one would assume that all aerosols consist of humic acid only. It is concluded that the processes leading to HONO formation on the Earth surface will have a much larger impact on the HONO-formation in the lowermost layer of the troposphere than humic materials potentially occurring in airborne particles.
\end{abstract}

Correspondence to: $\mathrm{M}$. Ammann

(markus.ammann@psi.ch)

\section{Introduction}

The formation of nitrous acid (HONO) in the atmosphere is of considerable interest as HONO is a major precursor of atmospheric hydroxyl radicals in the lowest layer of the troposphere (Acker et al., 2006b; Alicke et al., 2002, 2003; Aumont et al., 2003; Harrison et al., 1996; Kleffmann et al., 2005; Ren et al., 2003; Vogel et al., 2003; Zhou et al., 2002). Recent atmospheric measurements and model calculations (Acker et al., 2006b; Honrath et al., 2002; Kleffmann et al., 2003, 2005; Ren et al., 2003; Staffelbach et al., 1997; Vogel et al., 2003; Zhou et al., 2001, 2002, 2003) show a strongly enhanced formation of HONO during daytime, which is inconsistent with known gas phase formation mechanisms, direct emissions and heterogeneous processes occurring in the dark, i.e. during night. In our previous studies (George et al., 2005; Stemmler et al., 2006) it has been shown that nitrogen dioxide $\left(\mathrm{NO}_{2}\right)$ is effectively reduced to $\mathrm{HONO}$ on light activated surfaces containing humic acids, soil or selected synthetic aromatic compounds. The $\mathrm{NO}_{2} \rightarrow \mathrm{HONO}$ conversion rate on irradiated soil surfaces in contact with moderate $\mathrm{NO}_{2}$-concentrations was found to be sufficient to explain the high daytime concentrations of HONO observed in the near ground levels of the troposphere.

In this study the previous experiments on the photoreactivity of humic acid films and soil surfaces are extended to humic acid aerosol particles. This system has the advantage that aerosol flow tube studies allow a better characterization of the reaction conditions with regard to light intensity, to relative humidity, and especially to the surface area, than in the case of films with a potentially complex structure. This study also aims to investigate the behaviour of particulate matter of complex organic composition in aerosols and its processing

Published by Copernicus Publications on behalf of the European Geosciences Union. 
by atmospheric oxidants. It will provide an estimate of the significance of this process for HONO-formation on aerosol particles.

Humic substances are the most abundant group of organic species on the Earth surface (Batjes, 1996; IPCC, 2001; Janzen, 2004; Swift, 2001). They stem from the degradation of biological materials. As humic matter is ubiquitously found on ground surfaces, it is likely that such materials also exist on airborne surfaces (due to soil abrasion or biomass burning). Also atmospheric oxidation of VOC is a source of similar polymeric particle bound materials (Jang et al., 2002; Kalberer et al., 2004). More specifically, aromatic compounds typically present in biomass burning aerosol may undergo oxidation processes that lead to products similar to humic acids (Gelencser et al., 2003). Many studies focus now on the characterization of the complex organic material (the so called humic like substances) found in natural aerosol samples from different environments and search for the origins of these materials (Graber and Rudich, 2006). Such materials resemble in many properties the humic material found in the terrestrial or aquatic environment, but depending on the isolation methods and the type of analytical characterization significant differences between terrestrial and aquatic humic substances and aerosol borne humic-like substances were evident (Graber and Rudich, 2006). For example, airborne humic like matter appears to be of lower molecular size, may exhibit a lower aromaticity and a smaller light absorption in the visible range as compared to aquatic or terrestrial humic acids.

Despite these differences, a humic acid model compound (Aldrich Humic Acid) was chosen in this aerosol study, which shows a similar photoreactivity towards $\mathrm{NO}_{2}$ as humic acids from soil, brown coal or peat (Stemmler et al., 2006), but has a nearly tenfold higher photoreactivity towards $\mathrm{NO}_{2}$ during 400-700 nm irradiation compared to an aquatic fulvic acid (Suwannee River Fulvic Acid, Stemmler et al., unpublished results), the properties of which might be closer to that of humic like organic matter in aerosol (Graber and Rudich, 2006). Aldrich humic acid was chosen because it is available in sufficient quantities for the present experiments, it shows a sufficient photoreactivity to allow HONO formation being detected in an aerosol flow reactor, and because it allows a direct comparison with a previous study on stationary humic acid films (Stemmler et al., 2006).

\section{Experimental}

The experiments were performed in a horizontal aerosol flow tube $(190 \mathrm{~cm} \times 7.1 \mathrm{~cm}$ i.d.) at a pressure of $\sim 980 \mathrm{mbar}$. The glass flow tube was equipped with a movable $20 \mathrm{~cm}$ long Teflon plug, which bore conically widens to reach the flow tube dimensions, allowing an adjustment of the gas-aerosol contact time between 1 and $10 \mathrm{~min}(0-150 \mathrm{~cm}$ flow path length, $0.6-2.1 \mathrm{~L} \mathrm{~min}^{-1}$ gas flow). At the reactor exit, the gas flow was recollected by an identical Teflon plug. The reactor was installed in an air cooled lamp housing holding 7 fluorescence lamps $(150 \mathrm{~cm} \times 2.6 \mathrm{~cm}$ o.d. $)$, in a circular arrangement surrounding the reactor tube. Two types of lamps were used to examine the HONO-production under irradiation in the UV-A range (Philips Cleo Effect $70 \mathrm{~W}: 300-420 \mathrm{~nm}$ ) and in the visible part of the tropospheric light spectrum (Osram Lumilux Deluxe 954, $58 \mathrm{~W}: 400-750 \mathrm{~nm}$ ). The spectral actinic flux in the reactor was measured by a calibrated spectroradiometer (Hofzumahaus et al., 1999) with an optical receiver scaled down for the measurements in the flow tube and corrected for the imperfect angular response. Actinic flux spectra for the different sets of lamps are shown in Fig. 1a.

The humic acid particles were produced by nebulising a solution containing $20 \mathrm{~g} \mathrm{~L}^{-1}$ Aldrich humic acid sodium salt acidified to $\mathrm{pH} 4.6$ with $\mathrm{HCl}$ into a stream of $\mathrm{N}_{2}$. The nebulised humic acid was initially dried in a $1.2 \mathrm{~m}$ long Silica Gel diffusion drier, and then the particles were passed through a bipolar ion source $\left({ }^{85} \mathrm{Kr}\right)$ to establish an equilibrium charge distribution. An electrostatic precipitator removed all charged particles ensuring that only neutral particles were passing on through the experiment. The particles were rehumidified to the desired relative humidity and mixed with a prehumidified flow of $\mathrm{NO}_{2}$ in an $\mathrm{O}_{2} / \mathrm{N}_{2}-$ mixture before the entrance of the reactor. The final carrier gas was a 1:4 mixture of $\mathrm{O}_{2}$ and $\mathrm{N}_{2}$. The aerosol produced this way has a log-normal size distribution with a mean diameter of $100 \mathrm{~nm}$ and a geometric mean standard deviation of 1.85 at relative humidities of $20-40 \%$. Typical number, surface and mass concentrations were about $10^{6}$ particles $\mathrm{cm}^{-3}, 10^{-3} \mathrm{~cm}^{2} \mathrm{~cm}^{-3}$, and $5 \mathrm{mg} \mathrm{m}^{-3}$, respectively. Figure 1a shows the absorption spectrum of the employed humic acid in aqueous solution. The detailed structure of the aerosol produced from nebulising the acidified solution is not well known. The solution was presumably a suspension with a fraction of HA present in a colloidal form. We assume that the average composition of the aerosol still represented that of the solution, even though we have no information on the microstructure. Also the degree of protonation of HA in the aerosol is not known. Nevertheless, we believe that the aerosol produced this way is representing the organic fraction of e.g. soil dust.

The Reynolds numbers of the reactor under the given flow conditions were $\sim 12-43$ and indicate laminar flow conditions, but the laminar flow may be distorted by the fact that the reactor housing was heated by the lamps to about $300 \mathrm{~K}$ compared to the temperature of the entering gas of $296 \mathrm{~K}$. The heating of the gas on the warmer reactor walls is expected to induce some turbulence in the gas flow. Figure $1 \mathrm{~b}$ shows a residence time analysis of the aerosol particles in the flow tube. The reactor was operated at a total flow of $2.18 \mathrm{~L} \mathrm{~min}^{-1}$ corresponding to a calculated mean residence time of $t_{m}=180 \mathrm{~s}$. In Fig. 1b the aerosol concentration measured at the reactor exit during an "aerosol on-off" cycle is compared with modeled aerosol concentrations for plug 

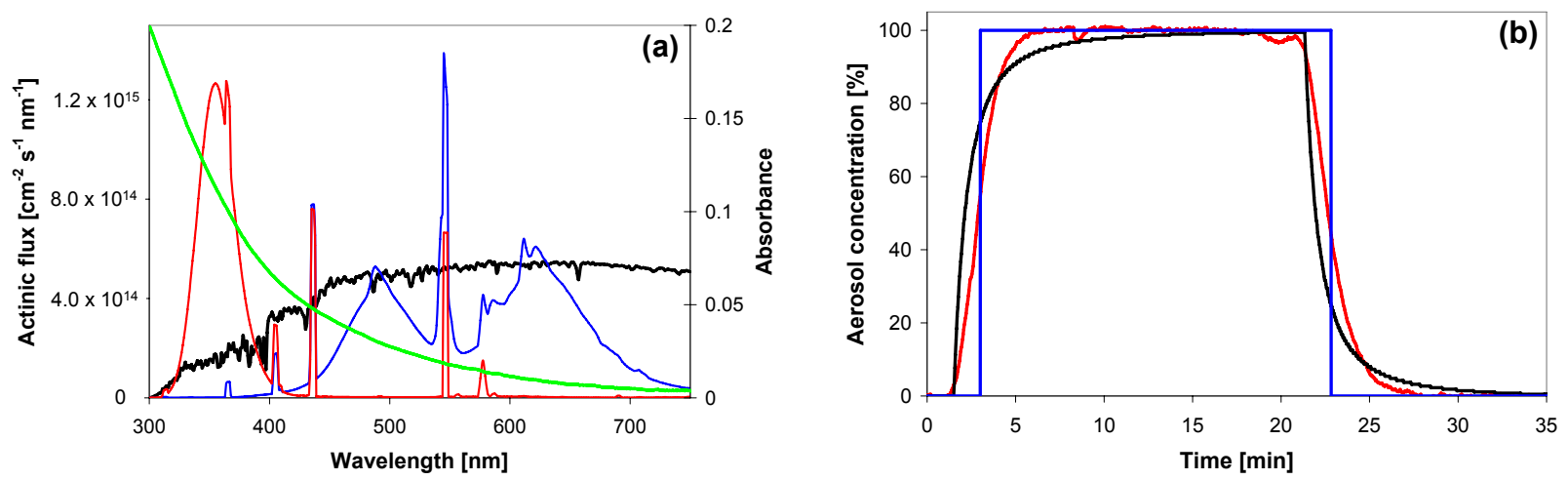

Fig. 1. Panel (a): Spectral actinic flux measured in the aerosol flow tube under visible and UV-A irradiation in comparison with the spectral actinic flux on the Earth surface and the absorption spectra of the humic acid. The red line depicts the spectrum of the UV-lamps; the blue line is for the visible lamps. The black line is the modelled clear sky actinic flux at the Earth surface for a Zenith angle of $40^{\circ}$, a ozone column of 300 DU, a surface albedo of 0 and a standard aerosol of the Tropospheric Ultraviolet and Visible Radiation Model (TUV version 4.3; NCAR, 2006). The absorption spectrum (base 10) of the employed humic acid in solution ( $\mathrm{pH} 4.3,10.5 \mathrm{mg} \mathrm{L}^{-1}$, pathlength $1 \mathrm{~cm}$ ) is shown as green line (right scale). Panel (b): Aerosol concentration measured at the reactor exit by an electrometer during a 20 min aerosol injection starting at $\mathrm{t}=0 \mathrm{~min}$ (red line, maximum concentration scaled to $100 \%$ ) in comparison with the aerosol concentrations modelled assuming plug flow (blue line) or laminar flow conditions (black line).

flow and for laminar conditions. The particle diffusion is neglected in the models. The first aerosol signal at the reactor exit is observed after $50 \%$ of the mean retention time $\left(t=t_{m} / 2\right)$ as expected for a laminar flow profile (Fitzer and Fritz, 1989). The comparison further indicates that the real residence time distribution is less tailing towards higher retention times than that expected from a laminar flow, indicating some radial transport in the flow tube. The reaction times given in this study refer to the calculated mean residence time. To justify this approach, the aerosol was injected for $20 \mathrm{~min}$ in each experiment to reach a homogeneous aerosol concentration in the reactor. The periods for which the aerosol concentration at the reactor exit was rising or falling due to the switch on-off were not used for the analysis, as it is expected that in these situations the aerosol exposure to $\mathrm{NO}_{2}$ was not constant.

The $\mathrm{NO}_{2}$-concentration entering the reactor was measured with a chemiluminescence detector (Monitor Labs 9841 $\mathrm{NO}_{\mathrm{x}}$-analyzer with a detection limit $0.5 \mathrm{ppb}$ and a precision of $\pm 5 \%$ ). This measurement was used for all $\mathrm{NO}_{2}$ concentrations in the reactor reported or used for analysis in this study. The aerosol concentration at the reactor entrance was measured by Scanning Mobility Particle Sizers (SMPS) consisting of a ${ }^{85} \mathrm{Kr}$ source reestablishing charge equilibrium on the aerosol, followed by a differential mobility analyzer (TSI Model 3071) and a condensation particle counter (TSI, Models 3022 and 3025, 13-777 nm, aerosol size range). At the exit of the reactor a LOPAP-instrument (Long Path Absorption Spectrometer) was used to determine the concentration of the reaction product $\mathrm{HONO}$ in the gas phase (Heland et al., 2001; Kleffmann et al., 2002, 2006). The instrument collects HONO by a fast chemical reaction in a stripping coil and converts it into a dye, which is measured in a long path absorption cell. Interferences for particles in the diameter range of the present study can be neglected, since the uptake of particles $<600 \mathrm{~nm}$ is found to be $\leq 1 \%$ (Bröske et al., 2003) and thus, the arising potential interferences are corrected for by the two channel instrument. In addition, based on our earlier study of $\mathrm{NO}_{2}$ conversion to $\mathrm{HONO}$ on solid anthracenetriol (Arens et al., 2002) we do not expect significant partitioning of HONO to the organic part of the HA aerosol. The instrument had a detection limit of 5 ppt and a total accuracy $\pm 10 \%$. The instrument was collecting two data points per minute, but its actual time resolution was 3 min under the employed operation conditions. $\mathrm{NO}_{\mathrm{x}}$ at the reactor exit was detected by means of a $\mathrm{NO} / \mathrm{NO}_{\mathrm{x}}$-chemiluminescence detector (CLD, Eco Physics, model CLD 77AM, with an external home made molybdenum converter at $653 \mathrm{~K}$ and a detection limit $0.1 \mathrm{ppb}$ and a precision of $\pm 1 \%$ ). The $\mathrm{NO}_{\mathrm{x}}-$ detector was used in combination with a sodium carbonate denuder tube $(50 \mathrm{~cm} \times 0.8 \mathrm{~cm})$ at the inlet of the analyzer to remove HONO from the gas stream and therefore eliminate the known interference of $\mathrm{HONO}$ in the $\mathrm{NO}_{2} \rightarrow \mathrm{NO}$ conversion. This detector was operated as an $\mathrm{NO}_{2}$ monitor during most of the experiments for quality assurance. It was used as an NO monitor (with the converter bypassed) during the $\mathrm{NO}_{2}$ photolysis experiments. Loss of $\mathrm{NO}_{2}$ in the reactor due to photolysis or reaction on the aerosol was below the detection limit in the $\mathrm{NO}_{2}$ mode. For a continuous relative measurement of the aerosol surface concentration at the reactor exit, charge equilibrium on the aerosol was reestablished using another ${ }^{85} \mathrm{Kr}$ source, and charged particles were deposited in an annular flow-through capacitor loaded by a $600 \mathrm{~V}$ battery. The current resulting from the total charge of 

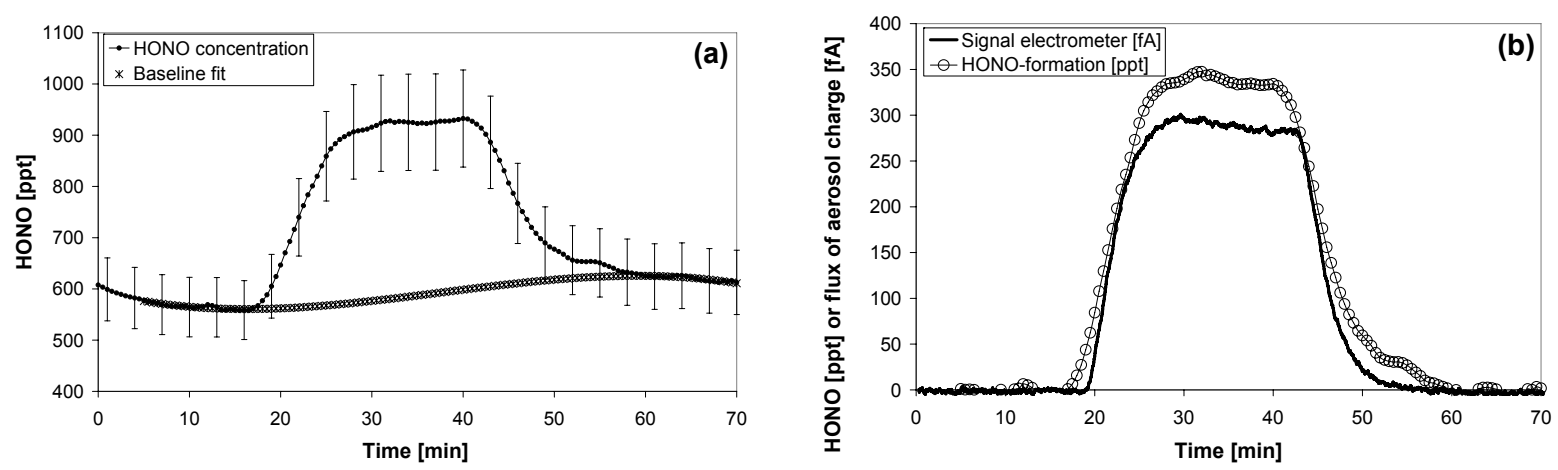

Fig. 2. Typical experimental result for the formation of $\mathrm{HONO}$ from gaseous $\mathrm{NO}_{2}$ on photoactivated humic acid aerosol. Panel (a): Measured HONO-concentration during the injection of the aerosol under visible light irradiation (400-750 nm). A significant HONO-formation (500$600 \mathrm{ppt}$ in this case) occurs on the reactor walls in the absence of aerosol. This background, which depends on the experimental conditions, the cleanness of the reactor, and the purity of gas and aerosol supplies was fitted before and after the aerosol injection (baseline fit) and was subtracted to obtain the excess HONO-formation on the comparatively small aerosol surface. Panel (b): Excess HONO-formation on the particle surface compared to the aerosol concentration measured at the reactor exit by the electrometer [fA].

one polarity was monitored by an electrometer. Offline experiments showed that the signal from this measurement is proportional to the surface concentration obtained from the SMPS, and therefore serves as a proxy for the aerosol surface area present in the reactor with high time resolution.

The general experimental procedure was the following: First the reactor was equilibrated under a given reaction condition (flows, length, humidity, light intensity, $\mathrm{NO}_{2}$ concentration). After equilibration, the conditions and the HONO-formation was monitored for $20 \mathrm{~min}$ in absence of the aerosol. Then, the aerosol was injected for $20-25 \mathrm{~min}$ by pumping the humic acid solution into the nebulizer and by bypassing an aerosol filter system. After the aerosol was switched off all parameters were monitored for another $20 \mathrm{~min}$ under the same conditions. This procedure was necessary as a significant HONO-concentration (150-900 ppt) was observed in the reactor in the absence of the aerosol. This background depended on the experimental conditions, the cleanliness of the reactor, and on the purity of gas supplies. As the aerosol surface in the experiments is small compared to the surface of the flow tube wall, heterogeneous processes on the reactor wall, such as heterogeneous hydrolysis of $\mathrm{NO}_{2}$ (Finlayson-Pitts et al., 2003) or reaction with deposited particles, lead to a significant background HONO-formation. It was therefore necessary to monitor this background HONO-concentration under all conditions and subtract it from the measured concentrations in presence of aerosols in order to obtain the excess HONO-formation on the particle surface. Typical experimental results for the HONO-formation during the injection of the humic acid aerosol and the procedure for the HONO-background subtraction are shown in Fig. 2.
For comparison purposes, some additional measurements, in which the photochemical HONO-formation was investigated on humic acid coatings, were performed with an experimental set-up described previously (Stemmler et al., 2006). This experimental set-up is briefly summarized here. The irradiations of the humic acid coatings were performed in $50 \mathrm{~cm} \times 0.8 \mathrm{~cm}$ Duran glass photo reactor cells installed in an air cooled lamp housing holding 7 fluorescence lamps $(44 \mathrm{~cm} \times 2.6 \mathrm{~cm}$ o.d. $)$, in a circular arrangement surrounding the reactor tube. The spectral distribution of the employed lamps (VIS-lamps: Osram Luminux Deluxe 954, 400-750 nm, UV-A lamps: Phillips Cleo Compact 300$420 \mathrm{~nm})$ are very similar to that of the lamps used in the aerosol study (Fig. 1a). But the integrated actinic fluxes in the coated wall flow tubes are $12 \%$ and $40 \%$ higher for the visible and UV-A irradiations, respectively. The inner surface of the tubular glass flow reactor (surface $=125 \mathrm{~cm}^{2}$, surface to volume ratio $=5 \mathrm{~cm}^{-1}$ ) was coated with a thin layer of humic acids. This glass reactor surface was sandblasted to prevent droplet formation during the coating procedure and therefore to reach a relatively homogeneous distribution of the organic test compound on the reactor walls. The humic acid coatings on the reactor wall were produced by gently drying $0.5 \mathrm{ml}$ aliquots of aqueous solutions of the humic acids dispersed on the reactor walls in a nitrogen stream at room temperature. In general, a quantity of $1 \mathrm{mg}$ of humic acid $\left(8 \mu \mathrm{g} \mathrm{cm}^{-2}\right)$ was used as coating. This amount had little effect on the spectral intensity distribution in the reactor, but was sufficient for a fast photochemical HONOproduction. The carrier gas flow (synthetic air) and the $\mathrm{NO}_{2}-$ addition, from a $959 \mathrm{ppb}$ mixture in synthetic air (Carbagas AG, Switzerland), was controlled by mass flow controllers. The total flow rate was $2.4 \mathrm{~L} \mathrm{~min}^{-1}$ at ambient pressure leading to gas residence times of $0.6 \mathrm{~s}$ in the photo-reactor. The 


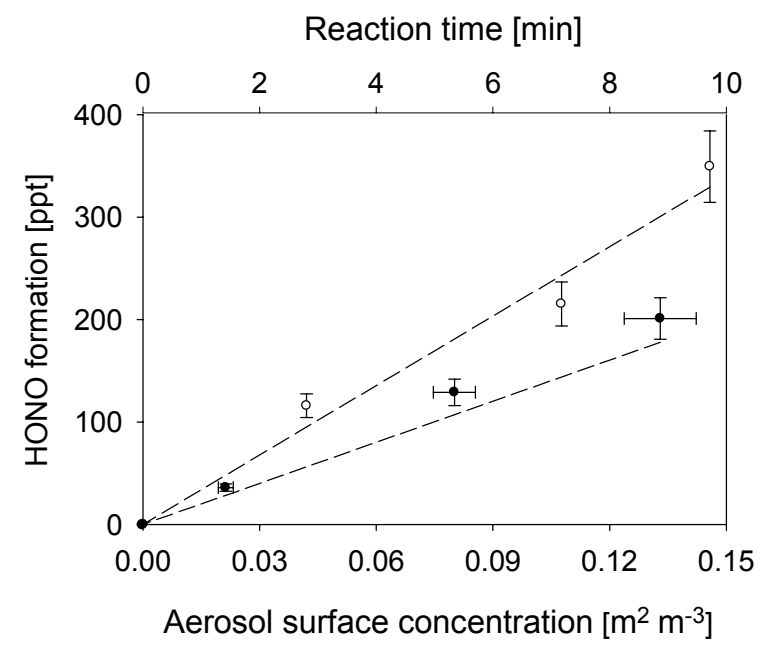

Fig. 3. HONO-formation on humic acid particles (see Fig. 2 for the raw data treatment) as a function of the aerosol surface concentration $(\bullet)$ and as a function of the reaction time (o). The aerosol surface concentration experiment is performed in presence of $79 \mathrm{ppb}$ $\mathrm{NO}_{2}$, at $26 \%$ relative humidity, and for a reaction time of $2.7 \mathrm{~min}$. The reaction time experiment was performed in presence of $44 \mathrm{ppb}$ $\mathrm{NO}_{2}$ and at $24 \%$ relative humidity and for an aerosol surface concentration of $0.082 \mathrm{~m}^{2} \mathrm{~m}^{-3}$. Both experiments were performed under visible light irradiation (Fig. 1). The black dashed lines represent a model description of the results (Eq. 4).

$\mathrm{NO}_{2}$-concentrations were adjusted in the 5-100 ppb range and the relative humidity between $0-50 \%$.

\section{Results and discussion}

As shown previously, $\mathrm{NO}_{2}$ is reduced on photo-activated humic acid containing surfaces to form HONO (Stemmler et al., 2006).

$\mathrm{NO}_{2}(\mathrm{~g}) \stackrel{\text { photoactivated aerosol surface }}{\longrightarrow} \mathrm{HONO}(\mathrm{g})$

In this study, this reaction was examined on the surface of submicron humic acid aerosol. The scheme of this reaction brought forward by Stemmler et al. (2006) and George et al. (2005) is essentially a one electron reduction of $\mathrm{NO}_{2}$ by reduced organic species enhanced by a photosensitizer. The corresponding dark reaction of $\mathrm{NO}_{2}$ with phenolic species with a HONO yield of nearly $100 \%$ is well established (Ammann et al., 2005; Arens et al., 2002, and references therein), however its kinetics is very slow under atmospheric conditions. Reaction (R1) is entirely different from the surface hydrolysis of $\mathrm{NO}_{2}$ leading to $\mathrm{HONO}$ and $\mathrm{HNO}_{3}$ (FinlaysonPitts et al., 2003). At low $\mathrm{NO}_{2}$ concentration, the surface hydrolysis is much slower than (R1) and also slower than the dark reaction of $\mathrm{NO}_{2}$ with phenolic species (Arens et al., 2002).

Figure 3 shows the dependence of the excess HONOformation on the humic acid aerosol on reaction time and

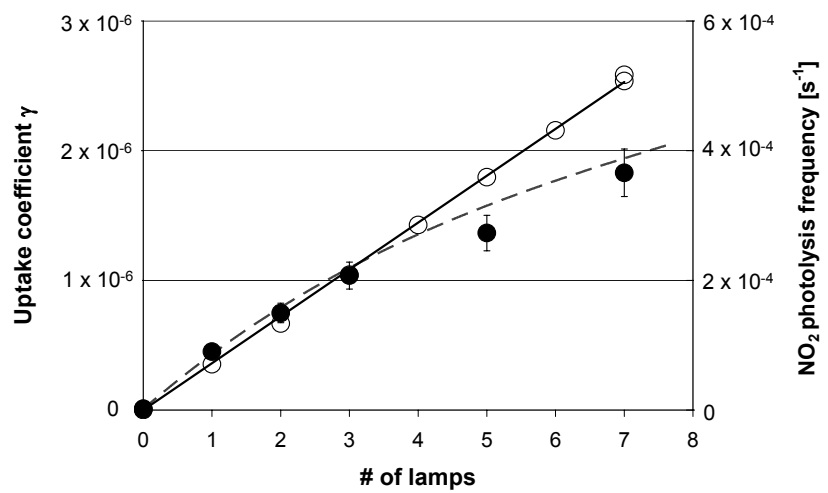

Fig. 4. Dependence of the HONO-formation on the visible light intensity expressed by the reactive uptake coefficient of $\mathrm{NO}_{2}$ on the aerosol surface (see Fig. 2 for the raw data treatment). The filled circles $(\bullet)$ are the derived uptake coefficients for HONOformation. The dashed black line represents a model description of the results (Eq. 5). The empty cycles (o) are experimentally determined $\mathrm{NO}_{2} \rightarrow \mathrm{NO}$ photolysis frequencies from experiments without aerosol. The black line is a linear fit of the data, indicating that the actinic flux in the reactor is proportional to the number of illuminated lamps.

on the aerosol surface concentration in the reactor. For the aerosol surface concentration dependency, all experiments were performed with the same polydisperse, log normal size distributed aerosol, the concentration of which was altered by changing the partial aerosol flow directed into the flow tube. Two SMPS systems were used to measure the aerosol surface concentration before and after dilution in parallel, the results of which agreed within $10 \%$ after correcting for the dilution factor. The HONO-formation depended linearly on the aerosol surface concentration $[\mathrm{S} / \mathrm{V}]$ and on the reaction time in the investigated interval of $0-10 \mathrm{~min}$ (i.e. $d \mathrm{HONO} / d t \propto[\mathrm{S} / \mathrm{V}]$ ).

The photochemical nature of the reaction is demonstrated in Fig. 4. Humic acid aerosol at a surface concentration of $0.110 \pm 0.005 \mathrm{~m}^{2} \mathrm{~m}^{-3}$ was introduced for periods of 20 $25 \mathrm{~min}$ into the reactor, which was equilibrated under different visible light actinic fluxes, and the HONO-concentration was measured at the reactor exit. The experiments were performed at a $\mathrm{NO}_{2}$-concentration of $35 \mathrm{ppb}$, a relative humidity of $30 \%$ and a reaction time of $3.75 \mathrm{~min}$. In Fig. 4, the HONO-formation rate is expressed as the reactive uptake coefficient $\gamma_{\mathrm{rxn}}$ of gaseous $\mathrm{NO}_{2}$ on the aerosol leading to the formation of HONO according to Reaction R1. The uptake coefficient $\gamma_{\mathrm{rxn}}$ is defined as the ratio between the rate of reactive collisions of $\mathrm{NO}_{2}$-molecules on the aerosol surface to form gaseous HONO and the gas-kinetic collision rate of the $\mathrm{NO}_{2}$-molecules with the particle surface. We thereby assume that the yield of HONO is $100 \%$ and neglect any other loss processes of $\mathrm{NO}_{2}$ on the particles that would lead to other products. 


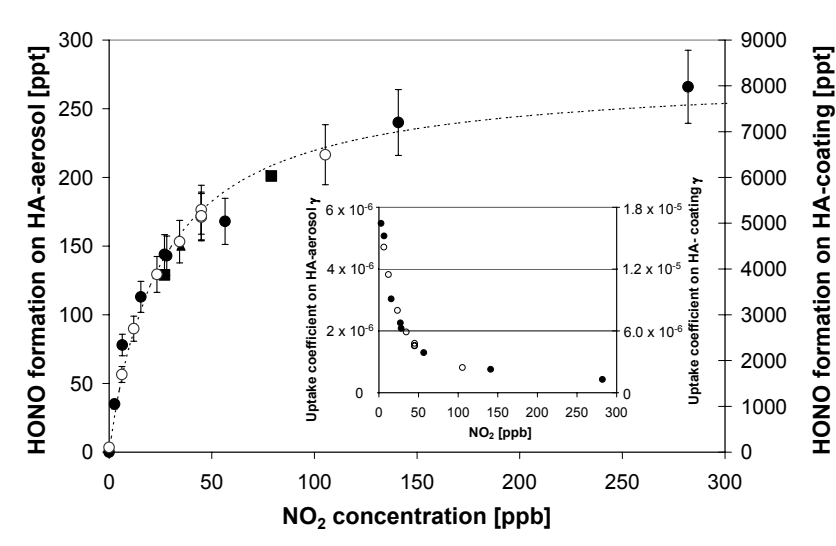

Fig. 5. Dependence of the HONO-formation on humic acid (HA) aerosols on the $\mathrm{NO}_{2}$-concentration (filled symbols). The experimental conditions are as follows: reaction time $2.8 \mathrm{~min}$, aerosol surface concentration $0.151 \pm 0.006 \mathrm{~m}^{2} \mathrm{~m}^{-3}$, relative humidity $26 \%$, actinic flux $1.0 \times 10^{17}$ photons $\mathrm{cm}^{-2} \mathrm{~s}^{-1}$ in the $400-750 \mathrm{~nm}$ range. The filled squares and the filled triangle are from the experiments in Fig. 3 (ם) and in Fig. 4 (ム) under most similar, but not completely identical conditions. The thin dashed line represents a model description of the results (Eq. 4). The empty circles (o, right scale) show the dependence of the HONO-formation on the $\mathrm{NO}_{2}$ concentration as observed on humic acid (HA) coatings at $21 \%$ relative humidity. The inset shows the dependence of the reactive uptake coefficient of $\mathrm{NO}_{2}$ on humic acid (HA) aerosol ( $\bullet$, left scale) and humic acid (HA) coatings (o, right scale) as a function of the $\mathrm{NO}_{2}$-concentration.

The observed first order rate coefficient for the transformation of $\mathrm{NO}_{2} \rightarrow \mathrm{HONO}$

$k_{1 \text {.order }}=-\ln \left(\frac{\left[\mathrm{NO}_{2}\right](t=0)-[\mathrm{HONO}](t)}{\left[\mathrm{NO}_{2}\right](t=0)}\right) \times t^{-1}$

is related to the uptake coefficient $\gamma_{\mathrm{rxn}}$ via Eq. (2), for which $[\mathrm{S} / \mathrm{V}]$ is the aerosol surface concentration measured during the experiment, and $\omega$ is the mean thermal velocity of $\mathrm{NO}_{2}$, given as $\omega=(8 R T /(\pi M))^{1 / 2}$ with $R, T$, and $M$ being the gas constant, the absolute temperature, and the molar weight of $\mathrm{NO}_{2}$, respectively.

$k_{1 . \text { order }}=\frac{\gamma_{\mathrm{rxn}} \times[\mathrm{S} / \mathrm{V}] \times \omega}{4}$

In the dark, the HONO-formation on the aerosol surface was below the detection limit, corresponding to an uptake coefficient $\gamma_{\mathrm{rxn}}<10^{-7}$. This upper limit is in agreement with the upper limit given for $\mathrm{NO}_{2} \rightarrow \mathrm{HONO}$ conversion on secondary organic aerosol particles in the dark (Bröske et al., 2003). The initial uptake coefficient of $\mathrm{NO}_{2}$ reacting with a film of 1,2,10-trihydroxyanthracene in the same concentration range is a few $10^{-6}$ (Arens et al., 2002), the higher reactivity being due to the absence of any electron withdrawing substituents, which are likely to be present in humic acids. The uptake coefficient of $\mathrm{NO}_{2}$ on humic acid aerosol increases with increasing actinic fluxes to $\gamma_{\mathrm{rxn}}=1.8 \times 10^{-6}$ at the maximum actinic flux of $1.0 \times 10^{17}$ photons $\mathrm{cm}^{-2} \mathrm{~s}^{-1}$ integrated over the $400-750 \mathrm{~nm}$ range of the lamp spectrum.

The HONO-production on the humic acid aerosol does not increase linearly with the actinic flux showing less than proportional reactivity at higher light fluxes. As proposed previously (Stemmler et al., 2006), this may indicate that the photo-produced reductive species $\left(\mathrm{A}^{\text {red }}\right)$ formed on the humic acid (HA) surface deactivate by reaction with photooxidants $\left(\mathrm{X}^{\mathrm{ox}}\right)$ formed simultaneously during the irradiation of humic acid surfaces in competition to their reaction with $\mathrm{NO}_{2}$ (Reactions R2, R3, and R4). The lifetime of $\mathrm{A}^{\text {red }}$ is therefore decreasing with increasing actinic flux.

$$
\begin{aligned}
& \mathrm{HA} \stackrel{\mathrm{h} v}{\longrightarrow} \mathrm{A}^{\text {red }}+\mathrm{X}^{\mathrm{ox}} \\
& \mathrm{A}^{\mathrm{red}}+\mathrm{X}^{\mathrm{ox}} \rightarrow \mathrm{HA}^{\prime} \\
& \mathrm{A}^{\mathrm{red}}+\mathrm{NO}_{2} \rightarrow \mathrm{HA}^{\prime \prime}+\mathrm{HONO}
\end{aligned}
$$

From the measured spectral actinic flux at full intensity (7 lamps illuminated), known absorption spectra, and quantum yields (Bongartz et al., 1994; Merienne et al., 1995; Troe, 2000), the photolysis frequencies of HONO and of $\mathrm{NO}_{2}$ in the reactor are calculated as $5.8 \times 10^{-5} \mathrm{~s}^{-1}$ and as $5.5 \times 10^{-4} \mathrm{~s}^{-1}$, respectively. This calculated photolysis frequency of $\mathrm{NO}_{2}$ is close to the measured value of $5.2 \times 10^{-4} \mathrm{~s}^{-1}$ (see Fig. 4) under the same light conditions. Experimentally, the photolysis frequencies of $\mathrm{NO}_{2}$ were determined from the measured $\mathrm{NO}$ yields at the reactor exit and by modelling according to the Leighton relationship (Reactions R5-R7).

$$
\begin{aligned}
& \mathrm{NO}_{2}+h v(<420 \mathrm{~nm}) \rightarrow \mathrm{NO}+\mathrm{O}\left({ }^{3} \mathrm{P}\right) \\
& \mathrm{O}\left({ }^{3} \mathrm{P}\right)+\mathrm{O}_{2}+M \rightarrow \mathrm{O}_{3}+M \\
& \mathrm{O}_{3}+\mathrm{NO} \rightarrow \mathrm{NO}_{2}+\mathrm{O}_{3}
\end{aligned}
$$

The linear increase of the $\mathrm{NO}_{2}$-photolysis frequencies with increasing number of lamps illuminating the reactor shows that the actinic flux in the reactor is proportional to the number of lamps used. Due to the small photolysis frequencies under the employed visible irradiation no correction for the loss of $\mathrm{NO}_{2}$ and $\mathrm{HONO}$ by photolysis was applied to the uptake coefficients, which lead to an underestimation of the uptake coefficients by about $5 \%$ for the typical experimental conditions. The ozone levels reached through Reactions (R5) to (R7) are a few ppb and are not considered to have any effect. Furthermore, scattering and absorption by the aerosol is estimated insignificant (smaller than 1\%) considering the path length, particle size, particle concentration and typical optical properties of humic-like aerosols.

Figure 5 shows the dependence of the HONO-formation on the $\mathrm{NO}_{2}$-concentration for the maximum actinic flux. The reaction is less effective at high (more than ambient) $\mathrm{NO}_{2}$-concentrations. This manifests in decreasing uptake 
coefficients between $5.5 \times 10^{-6}$ at $2.7 \mathrm{ppb}$ and $4.3 \times 10^{-7}$ at $280 \mathrm{ppb} \mathrm{NO}_{2}$. Figure 5 compares the HONO-formation on humic acid aerosol and on humic acid films coated on the walls of a glass photo-reactor (Stemmler et al., 2006). It is evident that a similar saturation curve is observed on both types of surfaces with increasing $\mathrm{NO}_{2}$-concentrations. In the inset the calculated uptake coefficients $\gamma_{\mathrm{rxn}}$ are compared for the aerosol experiments and for the experiments in the coated wall flow tube. The uptake coefficients for the coated wall flow tube are reanalyzed from data published by Stemmler et al. (2006), where no uptake coefficients had been derived. In the coated wall flow tube the first order reactive loss rate of $\mathrm{NO}_{2}$ according to Eq. (1) can be related to an uptake coefficient $\gamma_{\mathrm{rxn}}$ using Eq. (3):

$k_{1 . \text { order }}=\frac{\gamma_{\mathrm{rxn}} \omega}{2 r}$

In Eq. (3), $r$ is the flow tube radius $(0.4 \mathrm{~cm})$. However, Eq. (3) does not hold if gas phase diffusion limitations are present, i.e., when radial gas concentration profiles build up. To take into account gas phase diffusion, the Cooney-KimDavis (CKD) method (Cooney et al., 1974; Murphy and Fahey, 1987) was used to correct the measured uptake coefficients as described in detail by Behnke et al. (1997). Comparison of the CKD-corrected results with the uncorrected approach given by Eq. (3) was used to check to what degree uptake coefficients obtained in the coated wall flow tube were affected by gas phase diffusion limitations. At the highest observed uptake coefficients a maximum correction of $<25 \%$ was applied to account for the gas phase diffusion limitation. Contrary, the experimental results obtained from the aerosol flow tube experiments are not affected by the gas phase diffusion limitation under the given conditions.

The uptake coefficients derived from the humic acid coatings are approximately a factor of 3 higher than those obtained on the aerosol under comparable humidity and light conditions. The difference is probably related to uncertainties in the quantification of the humic acid surface areas. For the humic acid coatings the geometric surface of the inner surface of the glass reactor was used, a measure which must be viewed as an underestimation of the real surface, as it neglects any surface roughness of the sand blasted reactor surface and from the humic acid coating itself. We estimate this uncertainty in surface area to be up to a factor of 10 . For the surface area of the aerosol the surface measurement with a SMPS are used. The surface is calculated from the aerodynamic diameter assuming spherical particles, which may be not true as long as the particles are not deliquesced. Furthermore, the uncertainty of SMPS surface measurements is difficult to assess. A comparison of different SMPS instruments showed a standard deviation of up to $22 \%$ for the number concentrations and $10 \%$ for the diameter (which results in an estimated standard deviation of $26 \%$ in the surface concentration measurements) (Dahmann et al., 2001). Nevertheless, the uptake coefficients obtained on the aerosol sur- face are favoured as (i) the overall uncertainties in the surface area determination are much lower and as (ii) the knowledge of aerosol size distribution in the real atmosphere is mainly based on SMPS measurements allowing an easier comparison of the laboratory data with atmospheric conditions.

The hypothetical elementary photochemical mechanism (Reactions R2-R4), including activation of reductive centres $\left(\mathrm{A}^{\text {red }}\right)$ in the humic acid aerosol by light, the corresponding deactivation process, and the reaction of $\mathrm{A}^{\text {red }}$ with adsorbed $\mathrm{NO}_{2}$, predicts such a saturation curve for the HONOformation with increasing $\mathrm{NO}_{2}$-concentrations due to the competition of Reactions R3 and R4. But also alternative explanations, such as a Langmuir adsorption of $\mathrm{NO}_{2}$ coupled to a surface reaction, which is often referred to in heterogeneous chemistry (Ammann et al., 2003; Arens et al., 2001; Pöschl et al., 2001), can explain the observed saturation curve. $\mathrm{Nu}-$ merically, the two models can almost not be distinguished. However, motivated by the saturation behavior as a function of actinic flux, we suggest that reactions (R2) to (R4) are the more likely processes limiting reactive uptake in this case and use this scheme to parameterize the uptake coefficient.

As described previously (Stemmler et al., 2006) the saturation curve displayed by the concentration dependence can be analysed for the HONO-formation at low $\mathrm{NO}_{2}$-concentrations, which is first order in $\mathrm{NO}_{2}$ (i.e. $d(\mathrm{HONO}) / d t=k_{\mathrm{eff}}\left[\mathrm{NO}_{2}\right]$ ), and for the limiting rate of HONO-production at highly elevated $\mathrm{NO}_{2}$-concentration (i.e. $\left.d(\mathrm{HONO}) / d t=k_{\max }\right)$. From the data in Fig. 5 values of $k_{\mathrm{eff}}=4.3 \times 10^{-4} \mathrm{~s}^{-1}$ per $\mathrm{m}^{2} \mathrm{~m}^{-3}$ aerosol surface concentration and $k_{\max }=1.1 \times 10^{-23} \mathrm{ppb} \mathrm{s}^{-1}$ per m$^{2} \mathrm{~m}^{-3}$ aerosol surface concentration and per photon $\mathrm{m}^{-2} \mathrm{~s}^{-1}$ actinic flux are determined. With these parameters an empirical model description can be derived as described previously (Stemmler et al., 2006), which qualitatively describes the results for HONO-formation $(\triangle \mathrm{HONO})$ as a function of reaction time, aerosol surface concentration, light intensity, and $\mathrm{NO}_{2}-$ concentration.

$$
\begin{aligned}
\Delta \mathrm{HONO}[\mathrm{ppb}] & =\frac{t \times[\mathrm{S} / \mathrm{V}]}{k_{\max }^{-1} \times[F]^{-1}+k_{\mathrm{eff}}^{-1} \times\left[\mathrm{NO}_{2}\right]^{-1}} \\
& =\frac{t \times[\mathrm{S} / \mathrm{V}]}{9.3 \times 10^{22} \times[F]^{-1}+2330 \times\left[\mathrm{NO}_{2}\right]^{-1}}
\end{aligned}
$$

and the uptake coefficient $\gamma_{\mathrm{rxn}}$ is described correspondingly by

$\gamma_{\mathrm{rxn}}=\frac{4}{\omega} \times \frac{1}{9.3 \times 10^{22} \times\left[\mathrm{NO}_{2}\right] \times[F]^{-1}+2330}$

where $t$ is the reaction time in $\mathrm{s},[\mathrm{S} / \mathrm{V}]$ is the aerosol surface concentration in $\mathrm{m}^{2} \mathrm{~m}^{-3}, F$ the actinic flux in the $400-$ $750 \mathrm{~nm}$ range in photons $\mathrm{m}^{-2} \mathrm{~s}^{-1}, \omega$ is the mean thermal velocity of $\mathrm{NO}_{2}$ in $\mathrm{m} \mathrm{s}^{-1}$ and $\left[\mathrm{NO}_{2}\right]$ the concentration of $\mathrm{NO}_{2}$ in ppb. In Figs. 3-5 this model description is depicted by the dashed lines. 


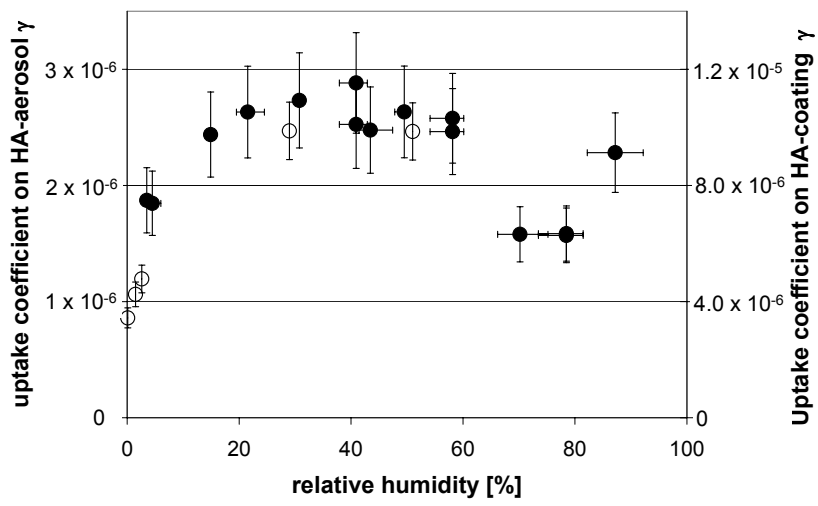

Fig. 6. Dependence of the HONO-formation on the relative humidity expressed as the uptake coefficients $\gamma_{\text {rxn }}$ on humic acid (HA) surfaces. The filled symbols depict the uptake coefficient measured on humic acid (HA) aerosols at $25 \mathrm{ppb} \mathrm{NO}_{2}$ and visible irradiation (left scale). The empty symbols depict the uptake coefficients measured on humic acid (HA) coatings at $20 \mathrm{ppb} \mathrm{NO}_{2}$ and visible irradiation (right scale). At high humidities (i.e. 88\%) it was visually observed that the humic acid coatings became deliquesced, preventing uptake measurements at such high humidities.

The parameterization given in Eqs. (4) and (5) is only valid for the given spectral distribution of the visible lamps used in this study. A comparison (Stemmler et al., 2006) of two different visible light sources (400-700 $\mathrm{nm}$ and 500$700 \mathrm{~nm}$ range) showed little differences with respect to the HONO-formation on humic acid coatings. Therefore, it is suggested that the reaction is only weakly dependent on wavelength in the visible region. Using UV-A lamps (300$420 \mathrm{~nm}, \lambda_{\max }=355 \mathrm{~nm}$ ) it was observed (Stemmler et al., 2006) that the HONO-formation from humic acid coatings was enhanced by approximately a factor of 3 compared to the visible irradiations, indicating a (relatively weak) wavelength dependence towards the UV-A range. The spectral actinic fluxes used were very similar to those in the aerosol flow tube (Fig. 1a). The aerosol experiment presented here is less suitable to investigate the HONO-formation on humic acid aerosol under UV-A irradiations, as both $\mathrm{NO}_{2}$ and $\mathrm{HONO}$ photolyse during the long reaction time. Nevertheless, an experiment using the UV-A light spectrum depicted in Fig. 1a was performed. The interpretation of the results is possible only if the system is modelled to account for $\mathrm{NO}_{2}$ and $\mathrm{HONO}$ photolysis. This was performed in a simplified way based on the $\mathrm{NO}_{2}$-photolysis (Reactions R5-R7), the HONO photolysis (Reaction $\mathrm{R} 8$ ), and the secondary reaction of $\mathrm{OH}$-radical with the gaseous species $\mathrm{NO}_{2}, \mathrm{NO}, \mathrm{O}_{3}$, and $\mathrm{HONO}$. Due to the involved modelling the results are less accurate.

$\mathrm{HONO}+h v(>400 \mathrm{~nm}) \rightarrow \mathrm{OH}+\mathrm{NO}$

A value of $\gamma_{\mathrm{rxn}}$ of $1.4 \times 10^{-6}$ is modelled for an initial $\mathrm{NO}_{2}$-concentration of $93 \mathrm{ppb}$ (which corresponds to an average $\mathrm{NO}_{2}$-concentration of $45 \mathrm{ppb}$ in the reactor due to
$\mathrm{NO}_{2}$-photolysis). This value is similar to the value observed at comparable $\mathrm{NO}_{2}$-concentrations (Fig. 5), but under visible irradiations. The absence of a clear enhancement of the HONO-formation under UV-A light, as expected from the UV-A experiments on the humic acid coatings (i.e. by a factor of $\approx 3$ under comparable light intensities), is likely explainable by the formation of ozone from the $\mathrm{NO}_{2}-$ photolysis, which is estimated to reach $49 \mathrm{ppb}$ in the photostationary state in the aerosol reactor. Ozone reacts in an analogous way and with comparable rates on the irradiated humic acid surfaces (unpublished results) as $\mathrm{NO}_{2}$ (Reaction $\mathrm{R} 1$ ) and therefore likely competes with $\mathrm{NO}_{2}$ for the reactive uptake on the humic acid aerosol. In addition, $\mathrm{OH}$ formed from photolysis of $\mathrm{O}_{3}$ and $\mathrm{HONO}$ in the reactor may also reach the HA surface and contribute to deactivation.

Figure 6 shows the $\mathrm{NO}_{2} \rightarrow \mathrm{HONO}$ conversion on humic acid aerosols as a function of relative humidity. At low humidity $(<10 \%)$ the aerosol shows a somewhat reduced reactivity, indicating that the presence of water promotes the reaction. A similar effect was observed on humic acid coatings at low humidity. In these experiments, which were characterized by a much higher $\mathrm{NO}_{2}$-conversion, it was evident that both, the loss of $\mathrm{NO}_{2}$ from the gas phase and the formation of gaseous HONO are affected identically. Therefore, it is not the partitioning of HONO that caused the effect. In the humidity range between 20 and $60 \%$ a constant reactivity of $\mathrm{NO}_{2}$ with humic acid aerosol was observed, which appears to drop somewhat at humidities above $60 \%$. The observed kinetic data can be compared with humidograms of Aldrich humic acid aerosol (Badger et al., 2006; Gysel et al., 2004). Gysel et al. report a steadily growing aerosol diameter upon hydration from 0-60\% relative humidity, which is believed to be due to water adsorption and solubilisation of the most soluble humic acid moieties, followed by an apparent size decrease between $60-75 \%$, which they attribute to the full deliquescence of the particle. The particles then homogenously grow further up to $90 \% \mathrm{RH}$ (total growth factor 1.18). In contrast, Badger et al. (2006) did not observe a deliquescence point of humic acid aerosol and suggested that the particles are deliquesced over the entire 0-90\% humidity range and that the aerosol may efflorescence only under extended residence times at zero humidity. From the present experiments one cannot decide at which humidity the aerosol gets deliquesced. However, we observed that a thin film of humic acid on a reactor glass surface visibly appeared deliquesced at $88 \%$ relative humidity. The increase of reactivity at low humidity observed here is similar to that observed for $\mathrm{NO}_{2}$ on anthracenetriol (Arens et al., 2002), on which increasing humidity was suggested to lead to an increasing degree of hydrolysis of the phenolic $\mathrm{OH}$ groups that is necessary to drive the reaction. A similar explanation might apply to the humic acid case. With further increasing humidity, the increasing amounts of water in adsorbed form or as an aqueous phase, which might be further promoted by the presence of solutes from the buffers used to adjust the 
$\mathrm{pH}$, may counteract the reaction in several ways. $\mathrm{NO}_{2}$ may be more soluble in pure (dry) HA than in an aqueous solution leading to a decrease of particle phase $\mathrm{NO}_{2}$ concentration with increasing humidity. The physical restructuring suggested by Gysel et al. (2004), who observed a decreasing aerodynamic diameter in the range between $60-75 \%$ relative humidity in their humidograms of monodisperse humic acid aerosol, would lead to a reduction of the true surface area and reduction of the uptake coefficient calculated by normalizing to the SMPS based surface area. Finally, and probably most likely, electron and energy transfer processes are strongly depending on the medium, and may be inhibited by an increasing number of water molecules between donor and acceptor.

Figure 7 shows the effects of the aerosol acidity on the formation of gaseous HONO. As nitrous acid is a weak acid ( $p K a=3.0-3.3)$ (da Silva et al., 2006; Park and Lee, 1988) it forms involatile nitrite salts in basic environments, which could be retained in the aerosol phase and would not be detected as gaseous HONO. Solutions of $20 \mathrm{~g} \mathrm{~L}^{-1}$ humic acid sodium salts were acidified with $\mathrm{HCl}$ to $\mathrm{pH} 3-7$ to produce humic acids with different degree of protonation. As humic acid contains large quantities of acidic organic functional groups they act as $\mathrm{pH}$-buffers over a wide $\mathrm{pH}$-range and stabilize the acidity of the aerosol depending on the degree of protonation. Figure 7 a demonstrates no significant change in the yields of gaseous HONO for moderate acidic to neutral aerosols. This indicates that nitrite salts are sufficiently rapidly desorbing as HONO to not affect the HONO-yields of the experiments with acid to neutral aerosols. As a comparison, also for water droplets, which may be viewed as a model for the humid humic acid aerosols, one would expect that less than $5 \%$ of the HONO is partitioning into the droplets at pH-values lower than 7.4, based on its Henry's law solubility $\left(43 \pm 3 \mathrm{M} \mathrm{atm}^{-1}\right.$ at $28^{\circ} \mathrm{C}$ (Park and Lee, 1988), its $p K_{a}$ of 3.3 (Park and Lee, 1988) and the total aerosol volume concentration in the experiment $\left(3.5 \times 10^{-3} \mathrm{~cm}^{3} \mathrm{~m}^{-3}\right)$, leading to an effective solubility of $<5.7 \times 10^{5} \mathrm{M} \mathrm{atm}^{-1}$. Figures $7 \mathrm{~b}-\mathrm{d}$ show the acidity dependence for the $\mathrm{NO}_{2} \rightarrow \mathrm{HONO}$ conversion on humic acid coatings, which gives more insights, as here also the $\mathrm{NO}_{2}$-removal can be observed due to the larger conversion. The $\mathrm{NO}_{2}$-removal and the HONO-production is compared for humic acid coatings produced from stock solutions acidified with phosphoric acid to $\mathrm{pH} 4.4,7.5$, and 10.3, respectively. At $\mathrm{pH} 4.4$ and with some constraint also at $\mathrm{pH}$ 7.5 , the formation of gaseous HONO is hardly retarded compared to the observed loss of gaseous $\mathrm{NO}_{2}$, whereas at $\mathrm{pH}$ 10.3 only a delayed evolution of gaseous HONO occurs. On the other hand, the loss of $\mathrm{NO}_{2}$ occurs instantaneously upon irradiation at all $\mathrm{pH}$-levels, and the magnitude of the $\mathrm{NO}_{2}$ consumption by the photoreaction is similar in all cases (7$8 \times 10^{10}$ molecules $\mathrm{s}^{-1} \mathrm{~cm}^{-2}$ ). This clearly indicates, that the rate of the photo-reduction of $\mathrm{NO}_{2}$ on the humic acid surfaces is not depending on $\mathrm{pH}$, but rather accumulation of the reaction product $\mathrm{HONO}\left(p K_{a}\left(\mathrm{HONO} / \mathrm{NO}_{2}^{-}\right) \approx 3.0-3.3\right.$, da Silva et al., 2006; Park and Lee, 1988) on the humic acid
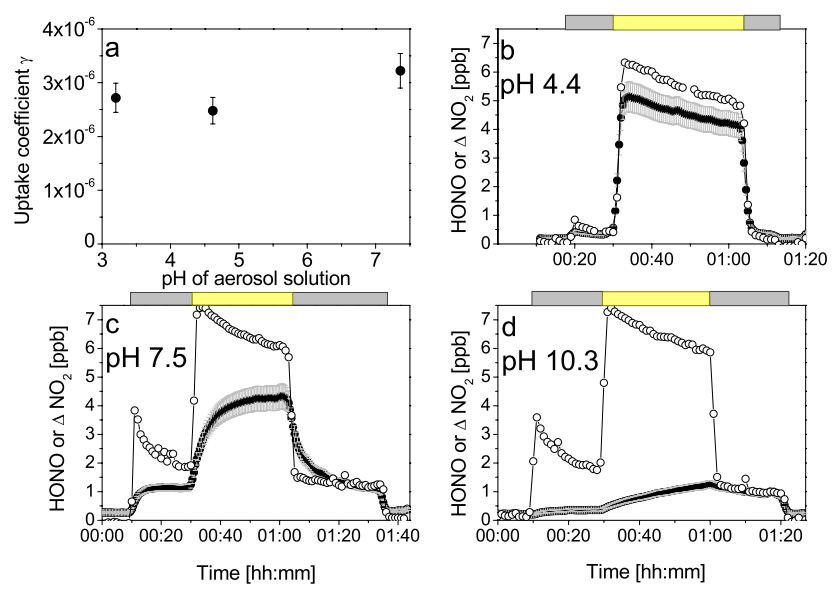

Fig. 7. Formation of $\mathrm{HONO}$ as a function of acidity of the humic acid aerosol and $\mathrm{HONO}$-formation and $\mathrm{NO}_{2}$-loss on humic acid coatings of different acidity. Panel (a): Uptake coefficient of $\mathrm{NO}_{2}$ on humic acid aerosol generated by nebulising humic acid solutions of $\mathrm{pH} 3.2,4.6$, and 7.4 in presence of $25 \mathrm{ppb} \mathrm{NO}$. Panel (b)-(d): Formation of $\mathrm{HONO}$ (filled circles) and removal of $\mathrm{NO}_{2}$ (empty circles) on humic acid coatings with different acidity. The coatings are produced from $1 \mathrm{mg} \mathrm{ml}^{-1}$ stock solutions with $\mathrm{pH} 4.4, \mathrm{pH} 7.5$, and $\mathrm{pH} 10.3$. The grey shaded area at the top of the panels indicate the periods where the humic acid surface was exposed to $\mathrm{NO}_{2}$ in the dark, the yellow area indicates the time, when the surface was irradiated $(400-750 \mathrm{~nm})$.

surface, which is much larger in the coated wall flow tube than in the aerosol flow tube and its travel time through the reactor increases with $\mathrm{pH}$. In the case of the HA coatings, this effect is more pronounced than in the aerosol case, because the ratio of the HA film volume to the reactor volume is much higher. This leads to increased partitioning of HONO to the condensed phase under the same acidity conditions, and, at similar HONO concentrations, it takes much longer for HONO to titrate the basic capacity of the film. The exchange of HONO between gas and condensed phase also leads to the delayed response observed at high $\mathrm{pH}$.

It appears that the dark reaction of $\mathrm{NO}_{2}$ with the humic acid coating increases with $\mathrm{pH}$, leading also to an enhanced formation of HONO. This effect is pronounced between $\mathrm{pH}$ 4.4 and 7.5, but a further increase between $\mathrm{pH} 7.5$ and 10.3 has not been detected. This might be related to the dark reaction between $\mathrm{NO}_{2}$ and the abundant phenolic groups or aromatic amines, within the humic acid and the reactivity of such compounds increases drastically with deprotonation (Ammann et al., 2005). But as deprotonation will additionally affect the conformation and the surface structure of humic acid, the observed changes cannot be related unequivocally to the direct effects of the deprotonation. 


\section{Conclusions and atmospheric implications}

In the presented kinetic experiments the photochemical formation of $\mathrm{HONO}$ by heterogeneous conversion of $\mathrm{NO}_{2}$ on humic acid aerosol surfaces was simulated under realistic atmospheric conditions with respect to humidity, $\mathrm{NO}_{2}-$ concentration, and actinic flux. However, the employed aerosol concentrations of $5-30 \times 10^{5}$ particles $\mathrm{cm}^{-3}$ are approximately a factor of 50 higher than the aerosol concentrations found in the urban or rural atmosphere $\left(10^{4}-\right.$ $10^{5}$ particles $\mathrm{cm}^{-3}$ ) due to experimental constraints. In the real atmosphere typical aerosol surface concentrations in the rural and urban atmosphere are $10^{2}-10^{3} \mu \mathrm{m}^{2} \mathrm{~cm}^{-3}$, respectively (Seinfeld and Pandis, 1997; Wehner and Wiedensohler, 2003). In the present experiments the aerosol surface concentrations are roughly 200 times higher and amounted between $2-14 \times 10^{4} \mu \mathrm{m}^{2} \mathrm{~cm}^{-3}$.

For $\mathrm{NO}_{2}$-concentrations of $10 \mathrm{ppb}$ and $20 \mathrm{ppb}$ (typical for rural and urban regions in Europe), an actinic flux of $1.7 \times 10^{17}$ photons $\mathrm{cm}^{-2} \mathrm{~s}^{-1}$ (typical clear sky flux in the $300-750 \mathrm{~nm}$ range, $40^{\circ}$ Zenith angle), relative humidities between $20-60 \%$ uptake coefficients in the order of $\gamma_{\mathrm{rxn}}=3.7 \times 10^{-6}$ and $2.6 \times 10^{-6}$ for the $\mathrm{NO}_{2} \rightarrow$ HONOconversion on humic acid aerosol are expected according to Eq. (5). Under the assumption that all aerosol is composed of humic acids and for typical aerosol surface concentrations of $100 \mu \mathrm{m}^{2} \mathrm{~cm}^{-3}$ for rural and $1000 \mu \mathrm{m}^{2} \mathrm{~cm}^{-3}$ for urban conditions, this leads to an estimated HONO-formation of $1.2 \mathrm{ppth}^{-1}$ and $17 \mathrm{ppth}^{-1}$ on aerosol surfaces in rural and urban environments, respectively. As mentioned earlier, the humic acid material used in the present study has a higher photo-reactivity than an authentic fulvic acid, which have also been suggested as a proxy of oxidized atmospheric organic matter. In reality rural and urban continental aerosol is composed only by 20-30 mass\% of organic matter (Hueglin et al., 2005; Putaud et al., 2004) and the photo-reactivity of these real existing airborne organic materials towards $\mathrm{NO}_{2}$ has never been shown. Therefore, these values should be considered as upper limits. These low upper limits for the HONO-production on humic acid aerosol can be compared with reports of daytime HONO-formation in near ground air over forested or rural sites of $170-500 \mathrm{ppth}^{-1}$ (Acker et al., 2006b; Kleffmann et al., 2005; Zhou et al., 2002) or in urban environments of up to $2 \mathrm{ppb} \mathrm{h}^{-1}$ (Acker et al., 2006a; Ren et al., 2003, 2006). In a previous study (Stemmler et al., 2006) the total photochemical HONO-production on an authentic soil sample was estimated as $5 \times 10^{10}$ molecules $\mathrm{cm}^{-2} \mathrm{~s}^{-1}$ for a urban pollution situation $\left(\sim 20 \mathrm{ppb} \mathrm{NO}_{2}\right)$ and solar irradiances $(300-700 \mathrm{~nm})$ of $\sim 400 \mathrm{Wm}^{-2}$. Such a HONOformation over sunlit soil is sufficient to establish a HONO source strength integrated over the lowest $100 \mathrm{~m}$ height of the atmosphere of $\sim 700 \mathrm{ppth}^{-1}$. Therefore, we suggest, that it is likely that photochemical HONO-formation on organic aerosol may be only a minor (or even no) contributor to the HONO-formation observed in the near ground atmosphere.
Only at places with exceptional high pollution by organic aerosol and nitrogen oxides, as in biomass burning plumes or in mega-cities, a comparable HONO-photo-formation on organic aerosol may occur.

Acknowledgements. K. Stemmler and M. Ammann appreciate the support by the Swiss National Science Foundation (project no. 200020-109341). The collaborative experiments were supported by the European Science Foundation within the project INTROP.

Edited by: Y. Rudich

\section{References}

Acker, K., Febo, A., Trick, S., Perrino, C., Bruno, P., Wiesen, P., Möller, D., Wieprecht, W., Auel, R., Giusto, M., Geyer, A., Platt, U., and Allegrini, I.: Nitrous acid in the urban area of Rome, Atmos. Environ., 40, 3123-3133, 2006a.

Acker, K., Möller, D., Wieprecht, W., Meixner, F. X., Bohn, B., Gilge, S., Plass-Dülmer, C., and Berresheim, H.: Strong daytime production of $\mathrm{OH}$ from $\mathrm{HNO}_{2}$ at a rural mountain site, Geophys. Res. Lett., 33, L02809, doi:10.1029/2005GL024643, 2006 b.

Alicke, B., Platt, U., and Stutz, J.: Impact of nitrous acid photolysis on the total hydroxyl radical budget during the Limitation of Oxidant Production/Pianura Padana Produzione di Ozono study in Milan, J. Geophys. Res., 107(D22), 8196, doi:10.1029/2000JD000075, 2002.

Alicke, B., Geyer, A., Hofzumahaus, A., Holland, F., Konrad, S., Pätz, H.W., Schäfer, J., Stutz, J., Volz-Thomas, A., and Platt, U.: $\mathrm{OH}$ formation by HONO photolysis during the BERLIOZ experiment, J. Geophys. Res., 108(D4), 8247, doi:10.1029/2001JD000579, 2003.

Ammann, M., Pöschl, U., and Rudich, Y.: Effects of reversible adsorption and Langmuir-Hinshelwood surface reactions on gas uptake by atmospheric particles, Phys. Chem. Chem. Phys., 5, 351-356, 2003.

Ammann, M., Rössler, E., Strekowski, R., and George, C.: Nitrogen dioxide multiphase chemistry: Uptake kinetics on aqueous solutions containing phenolic compounds, Phys. Chem. Chem. Phys., 7, 2513-2518, 2005.

Arens, F., Gutzwiller, L., Baltensperger, U., Gäggeler, H. W., and Ammann, M.: Heterogeneous reaction of $\mathrm{NO}_{2}$ on diesel soot particles, Environ. Sci. Technol., 35, 2191-2199, 2001.

Arens, F., Gutzwiller, L., Gäggeler, H. W., and Ammann, M.: The reaction of $\mathrm{NO}_{2}$ with solid anthrarobin (1,2,10-trihydroxy- anthracene), Phys. Chem. Chem. Phys., 4, 3684-3690, 2002.

Aumont, B., Chervier, F., and Laval, S.: Contribution of HONO sources to the $\mathrm{NO}_{\mathrm{x}} / \mathrm{HO}_{\mathrm{x}} / \mathrm{O}_{3}$ chemistry in the polluted boundary layer, Atmos. Environ., 37, 487-498, 2003.

Badger, C. L., George, I., Griffiths, P. T., Braban, C. F., Cox, R. A., and Abbatt, J. P. D.: Phase transitions and hygroscopic growth of aerosol particles containing humic acid and mixtures of humic acid and ammonium sulphate, Atmos. Chem. Phys., 6, 755-768, 2006, http://www.atmos-chem-phys.net/6/755/2006/.

Batjes, N. H.: Total carbon and nitrogen in the soils of the world, Eur. J. Soil Sci., 47, 151-163, 1996. 
Behnke, W., George, C., Scheer, V., and Zetzsch, C.: Production and decay of $\mathrm{ClNO}_{2}$ from the reaction of gaseous $\mathrm{N}_{2} \mathrm{O}_{5}$ with $\mathrm{NaCl}$ solution: bulk and aerosol experiments, J. Geophys. Res., 102, 3795-3804, 1997.

Bongartz, A., Kames, J., Schurath, U., George, C., Mirabel, P., and Ponche, J.L.: Experimental-determination of HONO mass accommodation coefficients using 2 different techniques, J. Atmos. Chem., 18, 149-169, 1994.

Bröske, R., Kleffmann, J., and Wiesen, P.: Heterogeneous conversion of $\mathrm{NO}_{2}$ on secondary organic aerosol surfaces: A possible source of nitrous acid (HONO) in the atmosphere?, Atmos. Chem. Phys., 3, 469-474, 2003,

http://www.atmos-chem-phys.net/3/469/2003/.

Cooney, D. O., Kim, S. S., and Davis, E. J.: Analyses of masstransfer in hemodialyzers for laminar blood-flow and homogeneous dialysate, Chem. Eng. Sci., 29, 1731-1738, 1974.

Da Silva, G., Kennedy, E. M., and Dlugogorski, B. Z.: Ab initio procedure for aqueous-phase pKa calculation: The acidity of nitrous acid, J. Phys. Chem. A, 110, 11 371-11 376, 2006.

Dahmann, D., Riediger, G., Schlatter, J., Wiedensohler, A., Carli, S., Graff, A., Grosser, M., Hojgr, M., Horn, H. G., Jing, L., Matter, U., Monz, C., Mosimann, T., Stein, H., Wehner, B., and Wieser, U.: Intercomparison of mobility particle sizers (MPS), Gefahrstoffe Reinhaltung der Luft, 61, 423-428, 2001.

Finlayson-Pitts, B. J., Wingen, L. M., Sumner, A. L., Syomin, D., and Ramazan, K. A.: The heterogeneous hydrolysis of $\mathrm{NO}_{2}$ in laboratory systems and in outdoor and indoor atmospheres: An integrated mechanism, Phys. Chem. Chem. Phys., 5, 223-242, 2003.

Fitzer, E. and Fritz, W.: Technische Chemie: Einführung in die Chemische Reaktionstechnik, Springer-Verlag, Berlin, 1989.

Gelencser, A., Hoffer, A., Kiss, G., Tombacz, E., Kurdi, R., and Bencze, L.: In-situ formation of light-absorbing organic matter in cloud water, J. Atmos. Chem. 45, 25-33, 2003.

George, C., Strekowski, R. S., Kleffmann, J., Stemmler, K., and Ammann, M.: Photoenhanced uptake of gaseous $\mathrm{NO}_{2}$ on solid organic compounds: A photochemical source of HONO?, Faraday Discuss., 130, 195-210, 2005.

Graber, E. R. and Rudich, Y.: Atmospheric HULIS: How humiclike are they? A comprehensive and critical review, Atmos. Chem. Phys., 6, 729-753, 2006, http://www.atmos-chem-phys.net/6/729/2006/.

Gysel, M., Weingartner, E., Nyeki, S., Paulsen, D., Baltensperger, U., Galambos, I., and Kiss, G.: Hygroscopic properties of water-soluble matter and humic-like organics in atmospheric fine aerosol, Atmos. Chem. Phys., 4, 35-50, 2004, http://www.atmos-chem-phys.net/4/35/2004/.

Harrison, R. M., Peak, J. D., and Collins, G. M.: Tropospheric cycle of nitrous acid, J. Geophys. Res., 101, 14 429-14 439, 1996.

Heland, J., Kleffmann, J., Kurtenbach, R., and Wiesen, P.: A new instrument to measure gaseous nitrous acid (HONO) in the atmosphere, Environ. Sci. Technol., 35, 3207-3212, 2001.

Hofzumahaus, A., Kraus, A., and Müller, M.: Solar actinic flux spectroradiometry: a technique for measuring photolysis frequencies in the atmosphere, Appl. Opt., 38, 4443-4460, 1999.

Honrath, R. E., Lu, Y., Peterson, M. C., Dibb, J. E., Arsenault, M. A., Cullen, N. J., and Steffen, K.: Vertical fluxes of $\mathrm{NO}_{\mathrm{x}}, \mathrm{HONO}$, and $\mathrm{HNO}_{3}$ above the snowpack at Summit, Greenland, Atmos. Environ., 36, 2629-2640, 2002.
Hueglin, C., Gehrig, R., Baltensperger, U., Gysel, M., Monn, C., and Vonmont, H.: Chemical characterisation of PM2.5, PM10 and coarse particles at urban, near-city and rural sites in Switzerland, Atmos. Environ., 39, 637-651, 2005.

IPCC: Climate Change 2001: The Scientific Basis. Chapter 3, Cambridge University Press, Cambridge, 2001.

Jang, M. S., Czoschke, N. M., Lee, S., and Kamens, R. M.: Heterogeneous atmospheric aerosol production by acid-catalyzed particle-phase reactions, Science, 298, 814-817, 2002.

Janzen, H. H.: Carbon cycling in earth systems - a soil science perspective, Agric. Ecosyst. Environ., 104, 399-417, 2004.

Kalberer, M., Paulsen, D., Sax, M., Steinbacher, M., Dommen, J., Prevot, A. S. H., Fisseha, R., Weingartner, E., Frankevich, V., Zenobi, R., and Baltensperger, U.: Identification of polymers as major components of atmospheric organic aerosols, Science, 303, 1659-1662, 2004.

Kleffmann, J., Heland, J., Kurtenbach, R., Lörzer, J., and Wiesen, P.: A new instrument (LOPAP) for the detection of nitrous acid (HONO), Environ. Sci. Pollut. Res., 9 (special issue 4), 48-54, 2002.

Kleffmann, J., Kurtenbach, R., Lörzer, J., Wiesen, P., Kalthoff, N., Vogel, B., and Vogel, H.: Measured and simulated vertical profiles of nitrous acid - Part I: Field measurements, Atmos. Environ., 37, 2949-2955, 2003.

Kleffmann, J., Gavriloaeiei, T., Hofzumahaus, A., Holland, F., Koppmann, R., Rupp, L., Schlosser, E., Siese, M., and Wahner, A.: Daytime formation of nitrous acid: A major source of $\mathrm{OH}$ radicals in a forest, Geophys. Res. Lett., 32, L05818, doi:10.1029/2005GL022524, 2005.

Kleffmann, J., Lörzer, J. C., Wiesen, P., Kern, C., Trick, S., Volkamer, R., Rodenas, M., and Wirtz, K.: Intercomparison of the DOAS and LOPAP techniques for the detection of nitrous acid (HONO), Atmos. Environ., 40, 3640-3652, 2006.

Merienne, M. F., Jenouvrier, A., and Coquart, B.: The $\mathrm{NO}_{2}$ absorption-spectrum. 1. Absorption cross-sections at ambienttemperature in the 300-500 nm Region, J. Atmos. Chem., 20, 281-297, 1995.

Murphy, D. M. and Fahey, D. W.: Mathematical treatment of the wall loss of a trace species in denuder and catalytic-converter tubes, Anal. Chem., 59, 2753-2759, 1987.

NCAR: Tropospheric Ultraviolet and Visible Radiation Model (TUV), National Center for Atmospheric Research, Boulder, CO, USA (http://cprm.acd.ucar.edu/Models/TUV/), 2006.

Park, J.-Y. and Lee, Y.-N.: Solubility and decomposition kinetics of nitrous acid in aqueous solution, J. Phys. Chem., 92, 6294-6302, 1988.

Pöschl, U., Letzel, T., Schauer, C., and Niessner, R.: Interaction of ozone and water vapor with spark discharge soot aerosol particles coated with benzo[a]pyrene: $\mathrm{O}_{3}$ and $\mathrm{H}_{2} \mathrm{O}$ adsorption, benzo[a]pyrene degradation, and atmospheric implications, J. Phys. Chem. A, 105, 4029-4041, 2001.

Putaud, J. P., Raes, F., Van Dingenen, R., Brüggemann, E., Facchini, M. C., Decesari, S., Fuzzi, S., Gehrig, R., Hueglin, C., Laj, P., Lorbeer, G., Maenhaut, W., Mihalopoulos, N., Müller, K., Querol, X., Rodriguez, S., Schneider, J., Spindler, G., ten Brink, H., Torseth, K., and Wiedensohler, A.: European aerosol phenomenology-2: chemical characteristics of particulate matter at kerbside, urban, rural and background sites in Europe, Atmos. Environ., 38, 2579-2595, 2004. 
Ren, X. R., Harder, H., Martinez, M., Lesher, R. L., Oliger, A., Simpas, J. B., Brune, W. H., Schwab, J. J., Demerjian, K. L., He, Y., Zhou, X. L., and Gao, H. G.: OH and $\mathrm{HO}_{2}$ chemistry in the urban atmosphere of New York City, Atmos. Environ., 37, 3639-3651, 2003.

Ren, X. R., Brune, W. H., Mao, J. Q., Mitchell, M. J., Lesher, R. L., Simpas, J. B., Metcalf, A. R., Schwab, J. J., Cai, C. X., Li, Y. Q., Demerjian, K. L., Felton, H.D., Boynton, G., Adams, A., Perry, J., He, Y., Zhou, X. L., and Hou, J.: Behavior of $\mathrm{OH}$ and $\mathrm{HO}_{2}$ in the winter atmosphere in New York city, Atmos. Environ., 40, S252-S263, 2006.

Seinfeld, J. H. and Pandis, S. N.: Atmospheric chemistry and physics: From air pollution to climate change, Wiley Interscience, New York, 1997.

Staffelbach, T., Neftel, A., and Horowitz, L. W.: Photochemical oxidant formation over southern Switzerland. 2. Model results, J. Geophys. Res., 102, 23 363-23 373, 1997.

Stemmler, K., Ammann, M., Donders, C., Kleffmann, J., and George, C.: Photosensitized reduction of nitrogen dioxide on humic acid as a source of nitrous acid, Nature, 440, 195-198, 2006.

Swift, R. S.: Sequestration of carbon by soil, Soil Sci., 166, 858871, 2001.

Troe, J.: Are primary quantum yields of $\mathrm{NO}_{2}$ photolysis at $\lambda \leq 398 \mathrm{~nm}$ smaller than unity?, Z. Phys. Chem. (Muenchen Ger.), 214, 573-581, 2000.
Vogel, B., Vogel, H., Kleffmann, J., and Kurtenbach, R.: Measured and simulated vertical profiles of nitrous acid - Part II. Model simulations and indications for a photolytic source, Atmos. Environ., 37, 2957-2966, 2003.

Wehner, B. and Wiedensohler, A.: Long term measurements of submicrometer urban aerosols: statistical analysis for correlations with meteorological conditions and trace gases, Atmos. Chem. Phys., 3, 867-879, 2003, http://www.atmos-chem-phys.net/3/867/2003/.

Zhou, X. L., Beine, H. J., Honrath, R. E., Fuentes, J. D., Simpson, W., Shepson, P. B., and Bottenheim, J. W.: Snowpack photochemical production of HONO: a major source of $\mathrm{OH}$ in the Arctic boundary layer in springtime, Geophys. Res. Lett., 28(21), 4087-4090, 2001.

Zhou, X. L., Civerolo, K., Dai, H. P., Huang, G., Schwab, J., and Demerjian, K.: Summertime nitrous acid chemistry in the atmospheric boundary layer at a rural site in New York State, J. Geophys. Res., 107(D21), 4590, doi:10.1029/2001JD001539, 2002.

Zhou, X. L., Gao, H. L., He, Y., Huang, G., Bertman, S. B., Civerolo, K., and Schwab, J.: Nitric acid photolysis on surfaces in low-NOx environments: Significant atmospheric implications, Geophys. Res. Lett., 30(23), 2217, doi:10.1029/2003GL018620, 2003. 